\title{
Protecting the Borderline and M inding the Bottom Line: Asylum Seekers and Politics in Contemporary Australia
}

\author{
Simon Phil pott
}

\begin{abstract}
In late 2001, the Australian government put asylum seekers at the centre of its re-election campaign by refusing to accept 438 asylum seckers picked up by the $N$ orwegian cargo ship Tampa. It then introduced legislation giving the Commonwealth powers to interdict asylum seekers at sea, and to forcibly return them to the port of embarkation. These measures extend the punitive regime of mandatory detention in privately owned and operated centres. This paper examines recent legislative and identity politics in the context of the long-standing white Australian fear of invasion from thenorth.
\end{abstract}

\section{Résumé}

Vers la fin de l'année 2001, le gouvernement australien plaça les demandeurs d'asile au centre de sa campagne électorale pour un nouveau mandat en refoulant 438 demandeurs d'asile recueillis par le navire cargo T ampa. Le gouvernement déposa ensuite un projet de loi conférant au Commonwealth des pouvoirs accrus lui permettant de stopper des demandeurs d'asile en haute mer et de les reconduire de force à leur port d'embarquement. Ces mesures étendent aussi la politique répressive de détention obligatoire dans des centres appartenant au secteur privé et exploités par le secteur privé. Cet article se penche sur les politiques légi slatives et identitaires récentes dans le contexte de la crainte qu'ont les australiens de race blanche de longue date d'une invasion venant du nord.

\section{Introduction and Political Context}

A ustralian social researcher Hugh M acKay regularly convenes focus groups to test thenational mood and gauge the temperature of certain issues. $\mathrm{H}$ is July meetings with voters indicated "strong... passions aroused by fears of illegal immigrants" from which heconcluded that the government's new policy of rejecting asylum seekers is "a calculated attempt to inflamethosefears and heighten our sense of insecurity for blatant political purposes." ${ }^{1}$ The new policy was a response to the "Tampa crisis" of August and September during which theAustralian government refused to allow 438 mainly Afghan asylum seekers to land on Australian soil, a decision which involved the Australian Special Air Services (SAS) taking command of the N orwegian container vessel the MV Tampa. The Tampa, at the request of Australian Search and Rescue (AusSAR), had picked up the asylum seekers from a small wooden fishing boat seventy-five nautical miles from Christmas Island (Australia) and 246 nautical miles from the Indonesian port of M erak on August 26. AusSAR instructed the captain of theT ampa, ArneRinnan, to sail for M erak wherepermission to land the asylum seekers had been given by the Indonesia Search and Rescue Authority. H owever, the asylum seekers protested this course of action and threatened the captain and his crew. Rinnan contacted authorities at AusSAR, told them of the situation and met no opposition to his request to makefor Christmas Island. H ewastold to anchor offshore once he arrived and await customs officials. But in the early hours of August 27, a Department of Immigration and Multicultural Affairs (DIM A) official acting on instructions from the secretary of thePrime Minister's department, contacted Rinnan, threatened charges for breaches of the $\mathrm{M} \mathrm{i-}$ 
gration Act, and instructed Rinnan to sail for Indonesia. H owever, Rinnan anchored his ship just outside Australian waters and waited while a heated argument developed between the Australian and N orwegian governments. Rinnan's repeated requests that a doctor be sent to the ship were ignored by theA ustralian government. Concerned about the deteriorating health of the asylum seekers aboard his ship and determined to secure medical assistance, Rinnan contacted the harbourmaster at Flying Fish Cove, Christmas Island, late in the morning of August 29 and informed him he was sailing into Australian waters. Within half an hour, the Prime M inister, John Howard, instructed the SAS to board and secure the ship, which was done by the early afternoon. Finally, on the evening of August 29, Rinnan, increasingly concerned about the health of the asylum seekers and their psychological state, sent an emergency "panpan" call, second only to a mayday call in its seriousness. An SAS doctor was provided and after about an hour concluded that no one on board was sufficiently ill to warrant being brought ashore. $^{2}$

But this three-day stand off was just the beginning of the Tampa affair. While the government succeeded in passing new legislation that makes it more difficult for asylum seekers to enter Australia and reduces their access to legal remedies oncethey have, it was not beforetheFederal Court became involved, and a High Court challenge to the legislation, ultimately unsuccessful, was announced by a private Australian citizen. Moreover, the Australian government has had a very public disagreement with the government of N orway, suffered severe damage to its diplomatic relations with Indonesia, and has suffered public and private criticism from the United Nations. Its attempts to prevent asylum seekers reaching Australia by diverting them to other countries for processing are continuing and currently involve N auru and Papua N ew Guinea. The government of Kiribati also offered its services whiletheF Fijian government finally rejected an Australian government request to house and process asylum seekers. ${ }^{3} \mathrm{M}$ ost significant, perhaps, has been the capitulation of the Australian Labor Party to government-fuelled populist outrageconcerning the "flood" of asylum seekers entering Australia. It has, with very few quibbles, supported the government's legislation and its new policy of, where possible, refusing to allow asylum seekers to land on Australian soil.

Just over two weeks after the so-called Tampa crisis began, a journalist attempted to calculate the cost of the operation to that point. He estimated expenditure of be tween $A \$ 70$ million and $A \$ 112$ million, or approximately $A \$ 160,000$ per head on the asylum seekers. This is between twice and 3.3 times as much as it would have cost to land and process the asylum seekersin the normal way. ${ }^{4} \mathrm{~T}$ hat the government could revitalize its flagging electoral fortunes while spending what appears to be a disproportionately large sum of money when a "decidedly bleak" mood of disenchantment with it prevailed reveals a great deal about the state of identity politics in contemporary Australia. ${ }^{5}$

Indeed, the "crisis" has provoked extraordinary political passions in Australia. Prior to being overwhelmed asa news event by the attacks on the World Trade Center and the Pentagon, newspaper based chat-rooms reported unprecedented volumes of correspondence and participation, much of it bitter and polarized. But thenew policy of simply refusing to accept asylum seekers arriving by boat appears to be a political master stroke on the part of the Prime $M$ inister, with newspaper and television polls consistently indicating overwhelming support for his actions. Cynical or not, John H oward's decision to stand up to the so-called illegals and queue jumpers continues his government's practice of applying the test of "national interest" to all instances in which "internationalist" co-operation or generosity is required. ${ }^{6} \mathrm{M}$ oreover, that the Australian government rejected UNHCR assurances that the Tampa "crisis" could be "solved very quickly" because N orway, the U.S., $\mathrm{N}$ ew Zealand, and Sweden had agreed to accept asylum seekers who qualified as refugees, indicates that human welfare may have been sacrificed for potential political gain. ${ }^{7}$

This article argues that the vilification of asylum seekers continues a discursive practice with origins in colonial Australia. Fears of invasion, of being swamped or overwhelmed by an Asian world routinely perceived as restive and hostile, have regularly characterized Australian debates about its future. The sight of even relatively small numbers of asylum seekers landing on Australian soil dissipates confidence that the qualities that define Australian national identity can survive, and swiftly undermines the oft-heard claims that Australians support the underdog, are profoundly egalitarian, and insist on a "fair go" for everyone. ${ }^{8}$ M oreover, despite the relatively small numbers of asylum seekers that have arrived by boat since the first five people arrived in Darwin harbour in April 1976, they have remained the objects of negative public opinion. ${ }^{9}$ This suggests that, in the absence of careful political management, there exists a potential threat to immigration, the refugee resettlement program, and the policy of multiculturalism that have been the foundation of Australia's ethnically plural society for most of the last three decades.

The discursive denigration of asylum seekers simultaneously fosters public hostility to them and creates the possibility for them being handed over to private sector control in which bottom-line considerations take precedence over concerns such as justice, dignity, or rights. Distancing the 
"asylum seeker" from the "citizen" enables new punitive regimes to be constructed and in ways that alleviate the government of responsibility precisely because asylum seekers are routinely regarded as being without rights because of their "criminal" conduct. ${ }^{10}$ The politics of legislative reform and the winding back of entitlements for asylum seekers are, therefore, explored in this article, as are specific issues arising from privatization of asylum-seeker care.

\section{Neo-liberalism and the Politics of Identity in Contemporary Australia}

There-election of theconservative Coalition government on November $10^{\text {th }}$ owed much to its uncompromising stance on asylum seekers. Indeed, at polling booths voters were greeted by posters of a stern-looking Prime M inister, standing at a lectern, fists clenched, with the words "We decide who comes to this country and the circumstances in which they come" emblazoned beneath his image. ${ }^{11}$ This continues a political history in which the peaks and troughs of John H oward's career have coincided with interventions on identity issues. As Opposition leader during the later 1980s, Howard was criticized for his public rumblings about the growing number of Asians among immigrants arriving in Australia and spoke out against the policy of multiculturalism which had enjoyed bipartisan support until he became leader of the Opposition. ${ }^{12}$ Negativity within the Liberal Party stirred up by his views was to cost $\mathrm{H}$ oward the leadership of the party in May 1989. But as desperate for an election victory as they were to find a leader that might deliver it to them, the Liberals again turned to $\mathrm{H}$ oward in 1995 and he delivered office in early 1996. H aving learned from his earlier (bitter) experiences, Howard has proven to be a shrewd if divisive manipulator of identity politics.

For example, the Coalition's ${ }^{13} 1996$ election campaign themewas "For All of Us". Theslogan implied, and H oward argued, that Labor had long since stopped listening to ordinary Australians and governed for cultural elites and minorities. Theseincluded theartscommunity, indigenous peoples, republicans, pro-Asianists, unionists, ethnic community lobbyists, and others whose visions for Australia were at odds with $\mathrm{H}$ oward's rather more traditional imagining of a nation of relaxed, comfortable, and happy nuclear families. However, opponents of the Coalition, especially indigenous Australians, quickly interpreted the slogan to mean, "For All of Us (but N ot Them)".

In government, John H oward was very slow to condemn the 1996 maiden parliamentary speech of independent M P Pauline $\mathrm{H}$ anson. The speech, xenophobic and often factually inaccurate, argued that indigenous people occupied a privileged place in Australian society and that harm was being done to Australia by immigration and the policy of multiculturalism. In the days following her incendiary comments, H oward observed that: "I thought some of the things that she said were an accurate reflection of what people feel." For weeks, H oward defended $\mathrm{H}$ anson on the grounds of free speech despite the absurdity of many of her allegations and claims. ${ }^{14}$ The government also desperately sought ways to limit native title claims arising from $\mathrm{High}$ Court decisions recognizing native title in 1992 and 1996. Its public (scare) campaign included a celebrated incident whereH oward wasinterviewed on television holding a map of Australia with large tracts of the continent shaded to demonstrate the alleged threat to "backyards" that native title implied. ${ }^{15}$

The Howard government's second term, perhaps tempered by a greatly reduced majority, was less explosive, though eventful.

H owever, the decision to put asylum seekers somewhere near the centre of an election campaign (albeit in the language of "defending Australia's borders") marks a significant shift in tactics on the part of the Australian government. Not only does it officially encourage a kind of empathy fatigue among existing Australian citizens and residents (including former asylum seekers and refugees), it follows upon legislative reforms that reduce the rights of asylum seekers to legal remedies and extend Commonwealth powers of interdiction at sea. M oreover, theferocity of the public backlash encountered by the Labor Opposition when it raised questions about aspects of the government's legislative response led it to support the Border Protection Bill in an attempt to salvage its dwindling electoral prospects. Arguably, the treatment of asylum seekers, particularly their mandatory detention, is now less open to challenge than at any time in the recent past. ${ }^{16}$ Yet, the lack of scrutiny of a policy pursued by only three other countries in the world, Greece, Turkey, and Poland, coincides with mounting evidence of ethical and other problems with the management of immigration detention centres by the privately owned firm, Australasian Correctional $M$ anagement Pty Ltd (ACM) ${ }^{17}$

\section{The D iscursive Construction of Incarceration}

How havethesemost desperate of peoplebeen so completely dehumanized that, at the height of the "Tampa crisis," different callers to talk-back radio in Australia called for them to be shot or forcibly restrained by the administration of sedative drugs? Arguably, the work of denigrating asylum seekers draws upon enduring historical narratives of threats from the north. Contemporary government discourses of danger (to Australian security) and management (of the human threats to sovereignty) merely burnish old fears and give them new focus. 
The arrival of asylum seekers in growing but modest numbers from the mid-1990s onwards partly fulfills the self-constructed nightmare of "invasion." That they arrive in relatively small numbers, unarmed, and with few resources, is irrelevant. ${ }^{18}$ Their presence both nourishes and adds to the deeply embedded cultural fear of invasion. And, under the circumstances of perceived externally derived threat to national and personal security, a surprisingly virulent hostility emerges in public discourse. D avid Walker has most impressively explored the long history of invasion fears in his book Anxious Nation where he notes the use of metaphors of flood and inundation a century ago, but with respect to the Chinese. ${ }^{19} \mathrm{M}$ oreover, in the context of contemporary asylum seekers, his comments concerning late nineteenth century fears remain apt:

By the 1880s it was commonplace to depict Asia as a world of huge populations 'teeming' with a terrible energy. Asia was a forceabout to engulf theworld'sunderpopulated zones. Added to thesepowerful stereotypes was thetheme of a malign O riental intelligence, patiently manoeuvring for advantage... ${ }^{20}$

Interestingly, among themost powerfully negativeimages of asylum seekers is that of the queue jumper, an expression routinely used by the government and media alike. It too resonates with theview of theAsian other as having a malign and advantage-seeking intelligence that offends the ordered and justice-seeking ways of ( white) Australians. But Ghassan $\mathrm{H}$ age reminds us that $\mathrm{A}$ sians are not always constructed as cool and calculating in their designs on Australia. Indeed, in the context of a discussion of Geoffrey Blainey's controversial book All for Australia (1984), $\mathrm{H}$ age refers to the image of an "irrational" (Asian) tide bearing down upon Australia:

It is their lack of rationality, compared to theW hite Australian, which constitutes them into such dangerous 'unthinking matter' inexorably moving to overtake Australia and which no reasoned argument can stop. ${ }^{21}$

Australian literature has also been liberally sprinkled with invasion scenarios, including John M arsden's Tomorrow When the War Began, a novel aimed at teenagers that has been reprinted twenty-six times since being published in 1994. ${ }^{22}$ Even during the years of so-called Asian engagement, Australians were presented with the rather stark alternative of dealing with Asia on its own terms, or simply being left behind in the scramble for economic development. ${ }^{23}$ The same images of being overwhelmed, swamped, diluted, or disappeared by Asian economic power are summoned as they are in more specifically racially motivated fears of military invasion. As former Labor immigration minister, Nick Bolkus, observes:

This is a frightened country ... For decades now we've been afraid of someoneinvading us from somewhereand I think that mentality still permeates much of the country. It is amazing the cross-section of the people who areinfiltrated with thisfear, the degree of xenophobia that exists as well, and envy. ${ }^{24}$

H owever, these remarks need elaboration because it is not a fear of all foreigners seeking refuge in Australia that pervades imaginings of invasion. That the panic is motivated by race and religious concerns and the image of the boat is demonstrated by the absencefrom detention centers of the two most numerous groups of "illegals," British and American nationals who have overstayed their visas and who constitute 20 per cent of "illegals." 25 Tracing the asylum-seeker issue through two Australian broadsheets, the Brisbane Courier Mail and the Sydney Morning Herald, between January 1997 and December 1999, Sharon Pickering's summary of the images used clearly relates the contemporary issue of asylum seekers to more traditional fears of Asian invasion:

According to the BCM and SMH we are soon to be 'awash', 'swamped', 'weathering the influx', of 'waves', 'latest waves', 'more waves', 'tides', 'floods', 'migratory flood', 'mass exodus' of 'aliens', 'queuejumpers', 'illegal immigrants', 'people smugglers', 'boat people', 'jumbo people' 'jetloads of illegals', 'illegal foreigners', 'bogus' and 'phoney' applicants, and 'hungry Asians' upon 'our shores', 'isolated coastlines', and 'deserted beaches', that make up the 'promised land', the 'land of hope', the 'lucky country', 'heaven', 'the good life', 'dream destination', and they continue to 'slip through', 'sneak in', 'gathering to our north', 'invade' with 'false papers' or 'no papers', 'exotic diseases', 'sicknesses' as part of 'gangs', 'criminal gangs', 'triads', 'organized crime', and 'Asian crime'. In response, 'we' should have 'closed doors', only sometimes having 'open doors', we should respond with the 'navy and armed services at the ready', 'we' should 'send messages', 'deter', 'lock up', and 'detain', 'we' should not be 'exploited', 'played for a fool', be seen as 'gullible' or be a 'forelock-tugging serf'. ${ }^{26}$

Since Pickering's article was published in mid-2001, two Australian ministers have supplemented the list with references to terrorists. On September 14, the M inister for Defence, Peter Reith, linked the refusal to land the Afghans on the Tampa and the more general "... clamp-down on border protection against boat people... . with efforts to combat terrorism."27 Four days later, on September 18, the Junior M inister for Finance, Peter Slipper, said: "There is an un- 
deniable linkage between illegals and terrorists... because... some of those people come from the country that is the centre of terror." Asked by journalists for evidence of this linkage, Slipper simply observed that because the socalled illegals were from the Taliban's Afghanistan, it was "... not beyond the realms of possibility..." that some asylum seekers may have been involved in terrorist activity. ${ }^{28}$ The undeniable link would appear in the context of the $M$ inister's own words to be rather more in the realms of speculation and hearsay.

Recent hostility towards M uslim asylum seekers has al so been worsened by a spate of rapes in Sydney attributed to Lebanese (M uslim) Australians whose victims were allegedly targeted for being "Australian." ${ }^{29}$ Journalist Paul Sheehan's comments on M uslim immigrants, poverty, crime, and violence led to an angry response from another Sydney M orning H erald journalist, Nadia Jamal, a Lebanese-Australian. ${ }^{30}$ The fact that both used statistical evidence to support contradictory arguments is indicative of the complexities of employing "science" to make sustainable claims about ethnicity. This is partly because fear, perhaps the most significant response aroused by the presence of immigrants and asylum seekers, is not amenable to empirical resolution and yet, like pain, when one is in its grip it can be overwhelming ${ }^{31} \mathrm{And}$, in this instance, fear is shadowed by anger in the form of "... growing anti-M uslim paranoia." 32

But the presence of increasing numbers of Muslims in Australia is, arguably, partly an unintended consequence of U.S. support for and arming of Islamic opposition to the Soviet presence in Afghanistan that eventually led to the emergence of the Taliban and its aggressive opposition to Saddam H ussein's regime in I raq. M oreover, the deregulation of Australia's economy and labour market over the last two decades has created a pervasive sense of insecurity in some sections of Australian society. I ronically, the Coalition government has probably gone further than its predecessors in promoting thealleged social benefits of economic deregulation even when it has meant economic pain and social dislocation. However, it has proven far more reluctant to renegotiate the fundamentals of what it means to be Australian in identity debate. Thus, unstructured, unregulated, and incalculable numbers of potential asylum seeker arrivals, a form of "globalisation from below" as Australian cultural theorist M cKenzie W ark describes it, threaten the government's control over identity issues. The very presence of the asylum seeker's body is a critique of national sovereignty and thetradeinequalities and developing world indebtedness that seems to be one feature of increasing globalization. The greater the inequalities in global trade, the more people join the flows of human beings escaping economic and political hardship. But discourses, such as those of some anti-globalization sentiment, that attempt to reassert the primacy of states cannot contribute to stemming the flow of people to the more privileged nations unless they systematically address the structural inequalities of the global economy. On this view, the effectiveness of political and economic barriers to outsiders erected by privileged nations will continue to be undermined because they recreate the very circumstances which lead to people fleeing entrenched disadvantage and the political violence characteristic of inequality. As W ark argues:

The most telling human critique of globalisation is not the black-clad protestors in Seattle or Genoa, it is the still, silent bodies of theillegals, in ships, trucks, car boots, passing through the borders. The placeless proletariat. ${ }^{33}$

But, Wark notes, missing from what he calls the new global disorder is a way to make a claim to a right outside of the space of thenation-state. The statel ess refugee simultaneously speaks of the presence of states failing in basic duties to citizens and the failure of other states to acknowledge responsibility for victims of the former.

In Australia, two factors have combined to enhance tensions about asylum seekers and immigration more generally. Firstly, it was during the 1980s that deregulation of the Australian economy commenced in earnest. This led to general erosion of wages and conditions as a result of the so-called Accords between successive Labor governments and the Australian Council of Trade U nions (ACTU) and to periods of high unemployment, high interest rates, and general feelings of insecurity in the Australian polity. Secondly, in the ten years prior to Labor's assuming office in early 1983, immigration from Asia accounted for approximately 21 per cent of the total, whereas in the ten years between 1983 and 1992 it accounted for more than 41 per cent. ${ }^{34} \mathrm{H}$ owever, the overall size of the immigration intake did not increase greatly, rising only from 1,008,376 during the decade 1970-79 (including a post-W orld War II high of 185,325 in 1970) to $1,068,128$ during the decade 1980-89. Moreover, very few asylum seekers arrived by boat between 1982 and late 1989.35 On this view, the tensions surrounding asylum seekers are an admixture to feelings of economic insecurity and the altered ethnic mix of the annual immigration intake rather than its increased size.

Supporters of Labor's attempts to broaden and deepen ties with Asia warned from the later 1980s onwards that it had failed to explain the alleged benefits of deregulation, immigration, and multiculturalism to the public. Feelings of insecurity about the future were intensified by threats to key institutions of the federation social contract, such as centralized wage fixing, and in the context of the bust that 
followed the 1980s boom. All this occurred at a time of growing unease, fostered by opponents of immigration and multiculturalism, about thenumbers of V ietnamese, Cambodians, and Lebanese in the immigration intake. ${ }^{36} \mathrm{~N}$ onetheless, and despite growing public discord with Labor's immigration policy, then Prime M inister Paul Keating argued forcefully against sporadic claims that Australia was being Asianized, saying in 1994: "W edo not, and cannot aim, to be 'Asian' or European or anything else but Australians." ${ }^{37}$

However, it was also in 1994 that the Keating Government introduced mandatory detention for asylum seekers after a brief period where unauthorized arrivals escalated. These were mainly Cambodians, Iraqis, and Afghans. Whilst the power to detain resided in the 1958 M igration Act, the move to mandatory detention reflected the then government's view that refugee advocates were making excessive use of court processes to prevent the removal of asylum seekers whose claims for refugee status had failed. Theidea of mandatory detention was to deter unauthorized arrivals. ${ }^{38}$

With the defeat of theK eating Government in 1996 came major changes, particularly in the context of Keating's image of Australia's as a confident, outward looking, cosmopolitan middle power. With "For All of Us," the Coalition touched upon an aggrieved sense in the community and shifted the focus of debates from Keating's so called big picture to an idea of "... security [that] has functioned... as a drive for historical, strategic, economic and ontological certitude." 39

In this environment, and ominously for asylum seekers, major dilemmas of justice and identity are reduced to tasks of management. ${ }^{40}$ In a broad critique of John Rawls and others who subscribe to what she calls virtue theories of politics, Bonnie Honig warns that anxieties arising from confrontations with political subjects that do not conform to ordered political institutions are intolerant and contribute to processes that reduce politics to administration and communitarian consolidation. ${ }^{41}$ Privatization of asylumseeker welfare is made possible because government attacks on peoplethat it calls "illegals," "queuejumpers," or "bogus refugees" implies their breach of administrative process and their abuse of the Refugee Convention, removing the need for government involvement. The criminalization of asylum seekers mitigates public sympathy and, simultaneously, brings into disrepute the Convention that protects asylum seekers. Sections of the media contribute to the denigration of the Refugee Convention by describing Australia's international treaty obligations as, for example, the "UN loophole," implying covert government conspiracies to admit asylum seekers or by calling upon extremist critics who provide profoundly negative assessments of asylum seekers. ${ }^{42}$ Front-page headlines such as theM elbourneH erald-Sun's "Alien Scam" sum up the negative impact the media can have on a political issue fraught with racialized fears. $^{43}$

\section{Privatizing Detention}

In A pril 1997, the Australian government sought proposals for the detention and management of peopledetained under the Migration Act from seventeen selected organizations. Australasian Correctional Management (ACM), a wholly owned subsidiary of the U.S.-owned Wackenhut Corrections Corporation, won the tender. The middle and upper management of the parent company, Wackenhut, is largely composed of former $\mathrm{FBI}$ and $\mathrm{CIA}$ operatives and the company has been subjected to a U.S. congressional investigation for its practices. It has also been connected to chemical and biological weapons producing consortiums. ${ }^{44} \mathrm{H}$ owever, the overall range of W ackenhut's activities is so extensive as to be beyond the scope of this article.45 The company's founder, former FBI agent George Wackenhut, apparently a great believer in incarceration, observed in a documentary aired on Australian television in late 2000 that: "They're [Australia] really starting to punish people, as they should have all along. This year we are going to make \$US400 million." 46 It is not clear whether Wackenhut's comments are squarely directed at asylum seekers in detention in ACM facilities but it is a disturbing picture of Wackenhut's understanding of the purposes of this aspect of his business. But it also conforms to the view, currently popular, if not encouraged by the Australian government, that asylum seekers ought to be punished.

ACM owns and operates six detention centres around Australia, in which are held approximately 3500 asylum seekers, including children, who account for about onethird of the detainees. In July 2001, it was reported that the profits of ACM had increased 350 per cent in two years on the back of increased numbers of asylum seekers reaching Australian shores. Annual turnover for ACM is A $\$ 200$ million, making Australia's Department of Immigration and Multicultural Affairs, Wackenhut's third-largest customer. ${ }^{47} \mathrm{As}$ a wholly owned subsidiary of a foreign corporation, ACM is not obliged to disclose detailed operating accounts, meaning it is difficult to determine what percentage of its operating revenueand profits are derived from the ownership and operation of the immigration detention centres compared to its prison operations. However, $A C M$ 's profits increased from $A \$ 4.1$ million in 1998 , to $A \$ 7.5$ million in 1999 , to $A \$ 14.75$ million in 2000 , and the rate of increase of profit more closely paral lels the increase in asylum seeker arrivals than growth in the prison population under ACM 's control. ACM accounted for about 20 
per cent of Wackenhut's gross revenues, 11 per cent of its consolidated revenues, and almost 50 per cent of Wackenhut Corrections Corporation's profit of US $\$ 19$ million in 2000. The M inister for Immigration, Philip Ruddock, acknowledged that the growth in ACM 's profits was a result of an increase in the numbers of asylum seekers reaching Australian shores in 2000.48

ACM's ability to make refugee detention profitable partly arises from its capacity to operate detention centres at a lower per-head cost than the government. For example, it has reduced the daily management cost of asylum seekers to approximately $A \$ 112$ per day, down from a high of A $\$ 145$ per day immediately before the Commonwealth handed control to the private sector in November 1997. Financial effectiveness, rather than the welfare of asylum seekers, has featured prominently in government discourse in favour of the privatized centres. For example, the performance measures of dignity and privacy have been removed from publicly available records concerning the contracts between ACM and the Commonwealth, and Freedom of Information requests on these issues have been denied for reasons of commercial confidentiality. ${ }^{49} \mathrm{O}$ this view, the profitability of ACM and the Australian government's desire to reduce the costs of compliance with the Refugee Convention take precedence over the needs and rights of asylum seekers. Indeed, notwithstanding ACM 's first right of refusal on the three-year contracts to run the detention centres and its desire to continue providing the service, the Australian government has invoked a clause in the agreement with ACM allowing it to tender for a new service provider on the grounds that ACM 's offer is not financially competitive. This is an exercise described by the M inister for Immigration as "... testing the market to obtain best value for money..." and may see a new service provider in the near future. ${ }^{50}$

But arguably, the related desires of the Australian government to save money and ACM 's desire to make it has been costly in every sense of the word, a point emphasized by the acting Commonwealth Ombudsman, Oliver Winder. In an investigation into the operation of the detention centres, Winder found:

... evidence at every IDC [Immigration Detention Centre] of self-harm, damage to property, fights and assaults, which suggested there were systematic deficiencies in the management of detainees... These observations raised serious concerns about the standard of care being provided to detainees. ${ }^{51}$

Allegations of brutality, sexual assault, and other denials of the rights of detainees have been common and have been investigated, but out of the public domain. Indeed, Philip
Flood, the Chair of a departmental inquiry (the M inister has consistently rejected calls for ajudicial inquiry, presumably because it would enable witnesses and perpetrators to be subpoenaed and would offer protection to those that wished to testify against ACM ), was scathingly critical of the handling of a series of serious allegations of impropriety against ACM staff. ${ }^{52}$ Commercial confidentiality prevents the public from knowing whether financial penalties were applied to ACM and, if so, their extent.

A Parliamentary committee also visited the six camps during 2001 and noted alleged assaults on detainees by ACM staff, poor facilities, inadequate medical treatment, and high levels of psychological anxiety arising from these circumstances. As one (Labor) committee member observed: "No one can visit these centres without being profoundly moved, nothing prepares you for the visible impact." Rejecting the parliamentary committee's recommendation that detainees be released after fourteen weeks, Immigration M inister Philip Ruddock, argued that committeemembers were "naïve" and lacked thelife experience to make such recommendations. ${ }^{53}$

Attempting to maintain the bottom line means that ACM facilities also have particularly harsh security measures. For example, in Villawood Detention Centre in Sydney, detainees are assembled four times a day and have to produce their photographic id and passes. ${ }^{54} \mathrm{ACM}$ officers, with two-way radios turned up to maximum volume and slamming doors behind them, check sleeping dormitories each hour of the night, generally in an invasive and aggressivemanner, including shining torches in the faces of sleeping detainees, adults and children alike. As one ACM employee observed: "Yes, many of my fellow officers are bastards to the detainees and treat them like dogs." The primary reason for this intrusiveness is to minimize escapes as they attract financial penalties under performancetargets set by the Commonwealth..$^{55} \mathrm{M}$ oreover, ACM 's drive for profits has contributed to its poor reputation with sections of the non-government welfare community. For example, when the Woomera detention centre was expanded, ACM pressured charitableorganizations to provideitems such as curtains and other materials associated with setting up the facility, as well as clothing for the detainees. It did not offer any payment for these goods, representing the detainees as people in need and therefore as deserving of assistance by the charities. At least one other commercial arrangement with St. Vincent de Paul was not honoured by ACM.$^{56}$

Minimizing costs, and the desire to maintain control over the flow of information in and out of the centres, also meant that they were very poorly equipped, particularly early in ACM 's contract. I nitially, children had no access to recreational facilities, not even balls. Adults were denied 
access to any kind of media, were not allowed to send or receive letters or to make or receive phone calls, and endured inadequate facilities as numbers in the centres swelled with new arrivals. Boredom has been noted as central to the regular bouts of protest and occasional violence in the camps. ${ }^{57}$ At least one recent review of ACM facilities indicates that they remain grossly inadequate. ${ }^{58}$

M edical care of asylum seekers may also be compromised by the imperative to keep costs under control. For example, a local doctor contracted to provide care to W oomera detainees noted that the dispensary at the camp did not fill at least one prescription he provided to an inmate because the drug was regarded as excessively expensive. The same doctor registered his concern that the intravenous administration of a particularly strong sedative to an agitated detainee by nurses took them out of their skills depth and was done in a clinic in which proper monitoring facilities were not available. ${ }^{59}$

The inability of the media and other non-government organizations to access detention centres means that it is difficult to determine how economic demands shapes dayto-day policy in the centres. But rioting, hunger strikes, instances of self-harm at the camps, and the tales of misery told by former detainees indicatethat there are many problems in the centres. Perhaps a policy of mandatory detention will inevitably produce problems of violence and unhappiness, but the profitability of ACM suggests that far more could be done to ease the anxiety and enhance the personal security and welfare of asylum seekers. Indeed, ACM also benefits from the undervalued labour of detainees, paying them approximately one-quarter of what the general prison population earns for similar work. Twelve hours labour may earn an asylum seeker a phone card worth $\$ 15$ or $\$ 20 .{ }^{60} \mathrm{~A}$ six-hour shift in the kitchen may pay $A \$ 10-15$ or a day cleaning latrines $A \$ 5 .{ }^{61}$ Arguably, this practice is possible only because $A C M$ is using what it calls "non-citizens" to undertake this work and because few peoplein Australia haveraised objections, the union movement having been noticeably silent on the issue of asylum seekers. Given that ACM is a profit-making concern, the use of labour that is not properly recompensed raises serious ethical questions.

There seems little doubt that despite government clai ms of taxpayer value for money in the detention and care of asylum seekers, the market has not been kind to asylum seekers themselves. They are compulsorily detained in facilities that at least two government-commissioned inquiries have condemned as inadequate. Their welfare is at least partly measured in terms of corporate profit. Perhaps of greatest concern is the fact that by placing the market between itself and asylum seekers, the Australian govern- ment, and the people it represents, can be shielded from the moral questions that might be raised by the policy of mandatory detention primarily in the context of commercial confidentiality.

The "crime" of asylum seekers is to have arrived in Australia without appropriate visas and other identity documents. This is a situation that British H ome Secretary Jack Straw acknowledges arises from the fundamental contradiction in the Refugee Convention that confers a right to apply for asylum but fails to impose a corresponding obligation on the part of governments to admit asylum seekers to enable them to exercise the right. ${ }^{62}$ Thus, arguably, the most vulnerable of peoplefind themselves not only stateless and in an uncertain legal real $m$ but in the hands of a company whose primary concern must, by definition, be the making of a profit from their incarceration. Protecting itself from the financial penalties that would have arisen from the breakout of rioting detainees at the Woomera detention centre in August 2000 dictated that employees of ACM use water cannon and tear gas on detainees, the only times in Australian history that such measures have been used against rioters. ${ }^{63}$ This is a stark reminder of the gulf between the treatment of citizens and "non-citizens" in contemporary Australia.

\section{Legislative "Reform" and Electoral Politics in the Wake of the Tampa}

A Conservative political commentator and a former senior member of John H oward's staff, Gerard Henderson, notes that in neither of two major foreign policy addresses in August in which the government's third-term agenda was outlined were refugees or asylum seekers mentioned by the Prime M inister.$^{64} \mathrm{~N}$ onetheless, when the decision was taken to refuse the Tampa permission to disembark its 438 asylum seekers later in August, the government took an opportunity not only to reinvigorate its electoral standing, but to draft new legislation in an attempt to deter asylum seekers. In sending theSAS to take control of the Tampa and in refusing to allow the asylum seekers to set foot on Australian soil (which would automatically invoke the M igration Act), the government argued that it was operating within the law. Whilst there was somedivision on this point, it was generally regarded that the government was within its rights. ${ }^{65} \mathrm{H}$ owever, on August $29^{\text {th }}$, it introduced the Border Protection Bill into the Parliament in an attempt to shore up its legal position and ensure that it was in breach of no laws. The legislation was to be retrospective and was to give the government the following powers, not just in respect to the Tampa, but all subsequent ships carrying asylum seekers.

Firstly, the government sought the power to remove any ship, without reason, from Australian waters. Secondly, the 
bill authorized the use of reasonable forceto removea ship. Thirdly, officers using such force and the Commonwealth itself wereto be immune from criminal or civil prosecution arising from its use. Fourthly, no decision to remove a ship from Australian waters was to be subject to judicial review. The bill also removed, for the purposes of migration, Ashmore reef (approximately 220 miles from the Australian mainland) and Christmas Island from territories mandated as Australia. ${ }^{66}$ Simon Evans from the Faculty of Law at M elbourne U niversity argued that the bill was dangerous on several grounds and publicly appealed to $M$ embers of the H ouse of Representatives and to Senators not to adopt the bill in its original form. Among his concerns was the lack of opportunity to scrutinize the bill with respect to the use of force. $\mathrm{He}$ e also noted that the discretion conferred on agencies of the Commonwealth to use force was absolute. He observed that there was an absence of preconditions for the use of force (including there being no requirement that instructions to leave Australian waters be understood by a ship's master, assuming there was one, and no requirement to check the seaworthiness of the vessel or the health of those on board). Healso raised concerns about the absence of judicial review of decisions to removeships or boats from Australian waters and argued the legislation probably did not comply with Australia's obligations under the Refugee Convention. ${ }^{67}$

Labor, having supported the government up to this time, opposed the legislation in its original form because it extended Commonwealth powers and combined with Australian Democrats and a Greens senator to defeat it in the Senate.

M eanwhile, the government engaged in a flurry of diplomatic activity. It attempted to engage Indonesia with the problem but failed as the Indonesian President, M egawati Sukarnoputri, allegedly furious at John Howard's public comments on Indonesia's responsibility for the asylum seekers, refused to take or return the calls of the Australian PrimeM inister. ${ }^{68}$ Indeed, the Indonesian Foreign M inister, $H$ assan W irayuda, accused the federal government of turning "... the issue of illegal immigrants into a political commodity..." ${ }^{69}$ Australia's relations with $\mathrm{N}$ orway al so quickly deteriorated into mutual and public criticism. ${ }^{70}$ The UNHCR criticized the government's decision and actions but was quickly rebuffed by thePrime M inister.$^{71} \mathrm{H}$ owever, as early as August $30^{\text {th }}$, the Australian Foreign Minister, Alexander Downer, contacted Sergio Vieira de M ello, the UN's chief administrator in East Timor, and requested that a refugee camp be made avai lable to house the 438 asylum seekers still stranded on the deck of the Tampa. The UN Secretary General, Kofi Annan, quickly intervened and vetoed the plan. ${ }^{72}$
Finally, on September 1, the government achieved the breakthrough it had sought. Nauru, the world's smallest republic with a population of just twelve thousand and notable for being an impoverished and ravaged former phosphate mine, was effectively bribed by the Australian government to accept the asylum seekers for processing. John Howard described this as "... a truly Pacific solution...," a statement of some audacity given that less than a month prior to the arrival of the Tampa, Howard had refused to attend the annual Pacific Islands Forum, held in N auru. ${ }^{73}$ The Australian government signed a Memorandum of Understanding guaranteeing N auru diesel to fuel the island's generators at a cost of about $A \$ 13 \mathrm{~m}$ per month until May 2002. Debts of $A \$ 1$ million owed to Australian hospitals by citizens of N auru were cancelled. The number of sporting and education scholarships provided to residents was doubled from ten to twenty and infrastructure assistance for maritime surveillance, telecommunications, and its airline were promised. ${ }^{74} \mathrm{As}$ a result of this deal, the asylum seekers were transferred from the MV Tampa to HMAS M anoora on September $3^{\text {rd }}$. Having been refused permission to transship the asylum seekers through Dili, the M anoora sailed for Pt. M oresby in Papua N ew Guinea.

Back in Australia, lawyer Eric Vadarlis and the Victorian Civil Liberties Council brought similar but separateactions in the Federal Court challenging the legality of the government's actions. On September 11 Justice N orth found that the asylum seekers had been illegally detained on the MV Tampa after their rescue on August 26. He instructed the M anoora, which by now had picked up a second group of mainly Iraqi asylum seekers, to return to Australia and disembark all theasylum seekers for processing. ${ }^{75} \mathrm{H}$ owever, the government appealed and on September 18th, the court overturned the decision of Justice N orth, arguing that the government indeed had the right to refuse entry to the asylum seekers. Significantly perhaps, the Chief Justice dissented in a 2-1 decision. However, the decision became redundant when Labor, having seen its electoral support plummet after opposing the original Border Protection Bill, agreed on September 18 to support it with minor amendments. These were that a vessel could only be returned to sea if it was seaworthy and that officers of the Commonwealth had to act in good faith and use no more force than was warranted if they were to avoid judicial scrutiny of their actions. ${ }^{76}$ In keeping with the government's concern with bottom line issues, it argues that one of the key aspects to its new legislation is reduction of costs associated with detention and processing of asylum seekers. ${ }^{77}$

The political imperative of recapturing or neutralizing the 936,621 voters (8.43 per cent of the votes cast) that supported Pauline Hanson's One Nation Party with its 
1998 election policies of zero immigration and temporary protection visas for refugees partly explains Labor's falling into line behind the government. In short, the Coalition proved itself willing to open up deep social divisions in the quest for electoral support and comprehensively outflanked Labor. Polling in the lead-up to the November 10 election showed that many former $\mathrm{O}$ ne $\mathrm{N}$ ation voters indicated their support for the Coalition. Indeed, as M argot Kingston notes in her analysis of the official Liberal Party campaign launch:

Only one other politician made it into the Howard snaps beamed onto the wall behind the podium before the speeches began. Philip Ruddock. He made it twice-H oward and Ruddock together, smiling in a sea of white faces on the street... It's theelection winner alright, the boat people. What mademy skin crawl was the thrill John Howard, Philip Ruddock and the Liberal crowd got from them... blood lust. Victory is ours. ${ }^{78}$

M ost of Australia's political journalists writing during the campaign concluded that through the "Tampa crisis" the government managed to recapture the vast bulk of One $\mathrm{N}$ ation supporters. ${ }^{79} \mathrm{On}$ this view, it is not surprising that Liberal party polling data shows Philip Ruddock is one of the government's most respected and admired ministers because of his consistent tough line on asylum seekers. Indeed, this information, which long precedes the appearance of the Tampa on the Australian horizon, may indicate the government's nascent awareness of the political possibilities of a calculated assault on asylum seekers and their rights. Peter $\mathrm{M}$ ares, author of a recent book on the treatment of refugees and asylum seekers in Australia, observes: "I come reluctantly to the conclusion that M r Ruddock is one of the government's frontline players in the shabby politics of division." 80

John Howard argues that it is in the Australian national interest that a line be drawn in the sand because of "... what is increasingly becoming an uncontrollable number of illegal arrivals." ${ }^{\text {81 }}$ But "uncontrollable" far better describes the circumstances that lead to many Afghans and I raqis fleeing their homes for the often expensive and highly dangerous flight to Australia by boat. Any attempt to control the flow of asylum seekers entails a meaningful engagement with the political and social circumstances that uproot people. In the unlikely event of that occurrence, an alternative would be the investment of reasonable resources much closer to the point of origin of asylum seekers so that their claims can be processed more expeditiously than is currently the case. The honorary Afghan consul in Australia, M ahmoud Saikal, likens securing a place through formal channels in the present system to winning a lottery. ${ }^{82}$ The enduring irony of the current situation is that the Australian government, through the so-called Pacific Solution, is now engaged in precisely the people trafficking it claims to abhor.

\section{Conclusion}

Asylum seekers reaching Australian shores have been subjected to a policy of mandatory detention since 1994 and have been in the hands of the private sector since late 1997. The policy of detaining all asylum seekers who arrive without appropriate documentation is pursued by only a small minority of countries and is a policy that concerns refugee advocate groups and the UNHCR. Despite government claims to the contrary, Australia is not unusually generous in the context of the numbers of refugees it resettles. In the context of comparatively small numbers of unauthorized arrivals compared to many other countries, mandatory detention of asylum seekers is not only a harsh response to vulnerable and often traumatized people, but also is central to a discursive regime of criminalization. Moreover, that asylum seekers are detained in sometimes remote and climatically inhospitable locations and in facilities routinely criticized for their poor quality demonstrates the distinctly regressive and punitive nature of the policy.

The Howard government's persistent arguments that value for money is important in managing asylum seekers is indicative of the prioritization of bottom-line considerations over basic human rights. Privatization of public utilities and other government services has generally been represented as legitimate to citizens not only because the service is provided more cheaply, but because the service is of a higher standard. The latter argument has not been made with respect to the welfare of asylum seekers. H owever, the capacity to transfer the care of asylum seekers from the state to the private sector arises in a broader historical context of hostility to perceived threats to Australian sovereignty and security arising in the north. While demonization of Asian "invaders" was routine in Australian political discourse from the middle decades of the nineteenth century, in the context of a more diverse and multicultural Australia, after about 1970, both major parties avoided blatant politicization of community concerns about immigration and multiculturalism. The Howard government has decisively broken with that bipartisanship and has been willing to place potential electoral gain ahead of the maintenance of social cohesion and the welfare of asylum seekers.

Government and media representations of asylum seekers as queue jumpers, illegals, bogus refugees and so on, have served to foment empathy fatigue among Australian citizens. M oreover, representations of asylum seekers as making unreasonable and extravagant claims upon Austra- 
lia and Australians, see them lumped together with other members of the so-called politically correct community in neo-liberal identity politics discourse. On this view, asylum seekers become another vector of UN "interference" in Australian affairs, a particularly sensitive issue given the UN's criticisms of the Howard government's policies towards indigenous peoples and women's rights. Successful denigration of asylum seekers as criminals and cheats not only enables the government to distance itself from their claims for consideration for residency in and citizenship of Australia, it brings the UN and the Refugee Convention into disrepute. At a time when the numbers of peoples of concern to the UN exceed twenty million, this development in an advanced and prosperous Western liberal democracy is of concern. Moreover, should countries like Canada, Britain, the U.S., and Germany follow the politically popular exampleset by Australia and forcibly closetheir borders, the al ready fragile architecture of global refugee management could suffer serious harm, particularly if poorer countries are saddled with even greater numbers of displaced peoples.

\section{Notes}

1. Hugh Mackay, "The Devil You Know," Sydney M orning Herald, 13 October 2001; online: <http:www.smh.com/news/ 0110/13/review/review3.html> (date accessed: 13 October 2001).

2. David M arr, "Arne Rinnan, a M an Who's N ot Like Usat All," Sydney M orning Herald, 22 December 2001; online: <http:www.smh.com.au/news/0112/22/opinion/opinion2.h tml> (date accessed: 22 December 2001).

3. Andrew Clennell, "Refugee Plan May Backfire, Says Ruddock," Sydney Morning Herald, 6 December 2001; online: <http://www.smh.com.au/news/0112/06/national/national5 .html > (date accessed: 6 D ecember 2001).

4. Mike Seccombe, "Do the Sums - It Doesn't Add U p," Sydney M orning Herald, 11 September 2001; online: <http://www. smh.com.au/news/0109/11/national/national6.html> (date accessed: 11 September 2001).

5. Mackay, "The Devil You Know."

6. Anthony Burke, "Australia's Asian Crisis," Australian Humanities Review (June 2001): 11; online: <http://www.lib.latrobe.edu.au/AHR/archive/Issue-June-2001/ burke/html> (date accessed: 15 October 2001).

7. Marian Wilkinson, "Canberra Rejected Tampa Plan," The Age, 20 October 2001; online: <http://www.theage.com.au/ news/national/2001/10/20/FFX1M 70V YSC.html> (date accessed: 200 ctober 2001).

8. The number of asylum seekers reaching Australian shores is comparatively small compared to the experience of European countries. DIMA statistics released on 4 July 2001 indicate 12,327 asylum claimants have arrived by boat since 1989 . The total for 1999-2000 was 4,174. In 2000, Britain received 97,660 asylum applications; Germany, 78,760; the Netherlands, 43,890; Belgium, 42,690; and France, 38,590. See William M aley, "Security, People Smuggling and Australia's N ew Afghan Refugees," Australian Journal of International Affairs 55, no. 3 (2001): 352.

9. Bob Birrell, "Why H oward Was Right," TheAge, 7 September 2001; online: <http://theage.com.au/news/state/ 2001/09/07/ FFXKQN WF9RC.htm I> (date accessed: 7 September 2001). Seealso David M arr, "Still Adrift," Sydney M orning Herald, 22 September 2001; online: <http://www.smh.com.au/news/ 0109/22/review/review3.html > (date accessed: 22 September 2001).

10. For example, outspoken Liberal Party senator Ross Lightfoot, in a letter to the editor of Australia's national newspaper, described asylum seekers as "criminals" and argued that may be carrying "communicable, pandemic, epidemic or parasitic diseases" and that their cultural differences and numbers threatened Australian security. Herecommended compulsory repatriation. See Ross Lightfoot, TheAustralian, 24 N ovember 1999, letters.

11. See an image of the poster online at <http://members.iinet.net.au/ postpub/8ball/data 11 meateater/ Howard_comp.html>.

12. Andrew Markus, Race: John Howard and the Remaking of Australia (Crows Nest: Allen \& Unwin, 2001) 87.

13. The Coalition istheLiberal Party of Australia and theN ational Party, the latter a small, rurally based party.

14. Markus, Race, 100-1.

15. Ibid., 42.

16. Labor remains deeply divided by mandatory detention in the wake of its disastrous electoral defeat. However, as of early February 2002, there are indications that Labor may abandon its support for the policy though no firm policy is yet being articulated.

17. As recently as late October 2001, the Inspector of Custodial Services in Western Australia, Professor Richard Harding, described immigration detention centres in Australia as "unacceptably overcrowded" and as providing "disgracefully inadequate medical and dental services." See The Age, "Detention Centres a Disgrace: W atchdog," 300 ctober 2001; online: <http://www.theage.com.au/news/national/2001/ 10/30/FFX95HJJ ETC.html> (date accessed: 30 October 2001).

18. The UN argues there are 3.5 million Afghan refugees in Pakistan, I ran, and India, whilein lateAugust 2001 it wasestimated that six thousand asylum seekers, mainly Afghans and Iraqis, might reach Australian shores beforetheend of theyear. There were 13,733 places in the refugee and special humanitarian in 2000- 1 of which 5,700 went to "illegal arrivals." Of the offshore places granted, 3,997 went to refugees and 3,116 to "special humanitarian grants." Germany accepted 95,110 refugees in 1999 and Britain 71,150. Australia is not in the top ten countries for the number of asylum seekers arriving without authorization. SeeAndrew Clennell, "O ur Refugee 'Crisis' Is a Drop in the O cean," Sydney M orning Herald, 30 August 
2001; online: <http://www. smh.com.au/news/0108/30/national/national8.html> (dated accessed: 30 August 2001).

19. David Walker, Anxious Nation: Australia and the Rise of Asia 1850-1939 (Brisbane: University of Q ueensland Press, 1999).

20. Walker, Anxious Nation, 7.

21. Ghassan Hage, WhiteN ation: Fantasies of White Supremacy in a M ulticultural Society (Annandale: Pluto, 1998), 221.

22. See <http://www.panmacmillan.com.au/johnmarsden/>.

23. M eaghan Morris, "White Panic or Mad Max and the Sublime," in Trajectories: Inter-Asia Cultural Studies, ed. KuanH sing Chen (London: Routledge, 1998), 255.

24. Peter M ares, Borderline: Australia's Treatment of Refugees and Asylum Seekers (Sydney: U NSW Press, 2001) 156.

25. Caroline Graydon, "Why New Refugee Laws Set a Bad Precedent," Sydney M orning Herald, 24 N ovember 1999; online: <http://www.smh.com.au/news/ 9911/24/features/features4.html> (date accessed: 24 N ovember 1999).

26. Sharon Pickering, "Common Sense and Original Deviancy: N ews Discourses and Asylum Seekers in Australia," Journal of Refugee Studies 14, no. 2 (2001): 172.

27. Tom Allard, "Reith Links Boat People, Terror Fight," Sydney M orning H erald, 14 September 2001.

28. Australian Associated Press, "M inister Claims Link between Boatpeople and Terrorists," Sydney M orning Herald, 18 September 2001; online: <http://www.smh.com.au/news/0109/ 18/national/national 100. ht $\mathrm{ml}>$ (dateaccessed: 18 September 2001).

29. Paul Sheehan, "M igrant FailureStories I nspired Passions over the Tampa," Sydney M orning Herald, 5 September 2001; online: <http://www.smh.com.au/news/0109/05/opinion/opinion1.html> (date accessed: 5 September 2001).

30. See N adia Jamal, "Incensed at Blaming Lebanese M uslims for the Woes of World," Sydney M orning Herald, 6 September 2001; online: <http://www.smh.com.au/news/0109/06/opinion/opinion 1.html> (date accessed: 6 September 2001) .

31. Linda Green, "Fear as a Way of Life," Cultural Anthropology 9 , no. 2 (1994): 230.

32. Jennifer Hewett, "Skipper H oward All at Sea without a M oral Compass," Sydney M orning Herald, 31 August 2001; online: $<$ http://www.smh.com.au/news/0108/31/opinion/opinion5 .html> (date accessed: 31 August 2001).

33. M cKenzie Wark, "Margot Kingston's Webdiary," Sydney M orning Herald, 31 August 2001; online: <http://www.smh. com.au/news/webdiary/0109/01/A59804-2001Aug 31.html> (date accessed: 31 August 2001).

34. See Markus, Race, 227.

35. Mares, Borderline, 68.

36. See Stephen Fitzgerald, Is Australia an Asian Country? Can Australia Survive in an East Asian Future (St. Leonards: Allen \& Unwin 1997).

37. Burke, "Australia's Asian Crisis," 7.

38. Birrell, "Why H oward Was Right."

39. Burke, "Australia's Asian Crisis," 3.

40. Ibid., 4.
41. BonnieH onig, Political Theory and the Displacement of Politics (Ithaca: Cornell University Press, 1993) 12-15.

42. Mares, Borderline, 87-88.

43. Ibid., 32.

44. "Of Jails, Spies and Chemical Weapons" The Guardian, 4 August 1999; online: <http://www.cpa.org.au/garchvel/965 wack.htm> (date accessed O ctober 4 2001).

45. See $M$ ares, Borderline, 69-72.

46. Bernard Lagan, "The More Punishment the Better to Fill George Wackenhut's Coffers," Sydney Morning Herald, 12 December 2000.

47. ACM 's operating revenues were $A \$ 191$ million in $2000, A \$ 102$ million in 1999, andA \$76 million in 1998.

48. Mark Colvin, "Rise in Asylum Seekers Increase Detention Profits," PM, 27 July 2001; online: <http://www.abc.net. au/pm/s336839.htm> (date accessed: O ctober 4 2001).

49. M ares, Borderline, 77.

50. Mark Colvin, "Govt to Tender Out Detention Centre Contract," PM , 25 May 2001; online: <http://www.abc.net.au/ pm/s302750.htm > (date accessed: 40 ctober 2001).

51. Agence France Presse, "Watchdog Slams Australian Immigrant Detention Centres," 5 March 2001; online: UNHCR Homepage <http://www.unhcr.ch/cgi-bin/texis/vtx/ home?page $=$ search $>$ (date accessed: 40 ctober 2001).

52. See M ares, Borderline, 3; UN HCR 2001.

53. BBC N ews Online: World: Asia-Pacific, "Australian PM Firm on Asylum Rules," 19 June 2001; online: <http://news.bbc.co. uk/low/english/world.asia-pacific/newsid_1396000/ 1396254.stm> (date accessed: 40 ctober 2001).

54. Lagan, "TheM orePunishment the Better to Fill GeorgeW ackenhut's Coffers."

55. Mares, Borderline, 61.

56. Ibid., 74-75.

57. Ibid.

58. The Age, "Detention Centres a Disgrace: Watchdog," $300 \mathrm{C}-$ tober 2001; online: <http://www.theage.com.au/news/ national/2001/10/30/FFX95HJ JETC.html> (date accessed: 30 October 2001).

59. M ares, Borderline, 44-45.

60. Lagan, "Themore punishment the better to fill GeorgeW ackenhut's coffers."

61. Mares, Borderline, 60-61.

62. Ibid., 185.

63. Ibid., 35.

64. Gerard Henderson, "H ow Foreign Policy turned on H oward," Sydney Morning Herald, 4 September 2001; online: <http://www.smh.com.au/news/0109/04/opinion/opinion1 .html (date accessed: 4 September 2001).

65. Sarah Crichton, "Australia H as Right to Board V essel," Sydney Morning Herald, 30 August 2001: online: <http://smh. com.au/news/0108/30/national/national5. html> (date accessed: 30 August 2001).

66. Simon Evans, "A Legal Expert's Perspective," Sydney M orning Herald, 29 August 2001; online: <http://www.smh.com.au/ 
news/0108/29/national/national400.ht ml> (dateaccessed: 29 August 2001).

67. Ibid.

68. Keith Loveard and Linda Doherty, "PM Unruffled as M egawati Fails to Call Back," Sydney M orning Herald, 1 September 2001; online: <http://www.smh.com.au/news/ 0109/01/national/national3.html> (date accessed: 1 September 2001). Seealso "Words That W ounded," Sydney M orning Herald, 7 February 2002; online: <http://www.smh.com.au/news/ 0202/07/national/graphic1.html> (date accessed: 7 February 2002).

69. Lindsay Murdoch and Andrew Clennell, "Politics behind Tampa Crisis, Says Indonesia," Sydney M orning Herald, 6 September 2001; online: <http://www.smh.com.au/news/ 0109/06/national/national11.html> (date accessed: 6September 2001).

70. Simon M ann, "H oward's Stance Absurd, Says N orway," Sydney M orning Herald, 30 August 2001; online: <http://www. smh. com.au/news/0108/30/national/national3.html> (date accessed: 30 August 2001).

71. Tom Allard and Sarah Crichton, "Share Refugees, Says U N," Sydney M orning Herald, 1 September 2001; online: <http:// www.smh.com.au/news/0109/01/national/national1.html> (date accessed: 1 September 2001). See also Patrick Barkham, "UN Attacks Canberra Blockade," The Guardian, 14 September 2001; online: <http://www.guardian.co.uk/Refugees_in_Britain/Story/0,2763,551784,00.html> (date accessed: 14 September 2001).

72. David Marr and Marian Wilkinson, "The Pacific Solution," Sydney Morning Herald, 22 October 2001; online: <http://www. smh.com.au/news/0110/22/national/national 15.html> (date accessed: 220 ctober 2001).

73. Hamish M cDonald, "Canberra Bullyboys Lack Intelligence to Stem the Tide," Sydney M orning Herald, 4 September 2001; online: <http://smh.com.au/news/0109/04/opinion/opinion2.html> (date accessed: 4 September 2001).

74. Sydney M orning Herald, "N auru Clinches Deal to Take Boatpeople," 10 September 2001; online: <http://www.smh.com. $\mathrm{au} /$ news/0109/10/national/national109.ht $\mathrm{ml}>$ (date accessed: 10 September 2001). See al so Sydney M orning Herald, "N auru's \$20m Australian Pay-off for Taking Refugees," 11 September 2001; online: <http://www.smh.com.au/news/ 0109/11/national/national5.html > (date accessed: 11 September 2001).

75. Sydney M orning H erald, "Government to Appeal Tampa ruling," 11 September 2001; online: <http://www.smh.com.au/ news/0109/11/national/national/104.html> (dateaccessed: 11 September 2001).

76. M argot Kingston, "Beazley Backs Howard's Tough Line on Boatpeople," Sydney M orning Herald, 18 September 2001; online: <http://www.smh.com.au/news/0109/18/national/national103.ht $\mathrm{ml}>$ (date accessed: 18 September 2001).

77. Border Protection (Validation and Enforcement Powers 2001) Bill 2001, Parliament of Commonwealth of Australia, Ex- planatory Memorandum, 3; online: <http://www.liberal. org.au/border/BPVEEM .pdf> (date accessed: 11 N ovember 2001).

78. M argot Kingston, "H oward'sAustralia," Sydney M orning Herald, 28 October 2001; online: <http://www.smh.com.au/ news/webdiary/2001/10/28/FFXX3RN OBTC.html > (dateaccessed 28 October 2001).

79. See, for example, Michelle Grattan, "Reprehensible Use of Boat People to Sink Labor," Sydney M orning H erald, 6 N ovember 2001; online: <http://www.smh.com.au/ballot01/ 0111/06. ballot2. html> (date accessed: 6 November 2001).

80. M ares, Borderline, 160.

81. Allard and Crichton, "Share Refugees, Says U N."

82. Clennell, "Our Refugee 'Crisis' Is a Drop in the Ocean."

Dr Simon Philpott is Lecturer in International Relations at the University of $\mathrm{N}$ ewcastle, England. He is the author of Rethinking Indonesia: Postcolonial Theory, Authoritarianism and Identity. 